\title{
'THE ODIOUS DEMON FROM ACROSS THE SEA'. OLIVER CROMWELL, MEMORY AND THE DISLOCATIONS OF IRELAND
}

\author{
Sarah Covington
}

As with any country subject to colonisation, partition, and dispossession, Ireland harbours a long social memory containing many villains, though none so overwhelmingly enduring — indeed, so historically overriding — as Oliver Cromwell. Invading the country in 1649 with his New Model Army in order to reassert control over an ongoing Catholic rebellion-turned royalist threat, Cromwell was in charge when thousands were killed during the storming of the towns of Drogheda and Wexford, before he proceeded on to a sometimes-brutal campaign in which the rest of the country was eventually subdued, despite considerable resistance in the next few years. Though Cromwell would himself depart Ireland after forty weeks, turning command over to his lieutenant Henry Ireton in the spring of $165^{0}$, the fruits of his efforts in Ireland resulted in famine, plague, the violence of continued guerrilla war, ethnic cleansing, and deportation; hundreds of thousands died from the war and its aftermath, and all would be affected by a settlement that would, in the words of one recent historian, bring about 'the most epic and monumental transformation of Irish life, property, and landscape that the island had ever known'. ${ }^{1}$

Though Cromwell's invasion generated a significant amount of international press and attention at the time, ${ }^{2}$ scholars have argued that Cromwell as an embodiment of English violence and perfidy is a relatively recent phenomenon in Irish historical memory, having emerged only as the result of nineteenth-century nationalist (or unionist) movements which

1 William J. Smyth, Map-making, landscapes, and memory. A geography of colonial and early modern Ireland, $1530-1750$ (Notre Dame: University of Notre Dame Press in association with Field Day, 2006), 196. For a more recent treatment of Cromwell, see Micheál Ó Siochrú, God's executioner. Oliver Cromwell and the conquest of Ireland (London: Faber \& Faber, 2008).

2 Michaél Ó Siochrú, 'Propaganda, rumour and myth. Oliver Cromwell and the massacre at Drogheda', in David Edwards, Pádraig Lenihan and Clodagh Tait (eds.), Age of atrocity. Violence and political conflict in Ireland, $1550-1650$ (Dublin and Portland: Four Court Press, 2007), 266-282. 
constructed traditions or shaped memories around him in order to justify their respective causes. As Toby Barnard has written, Irish histories of the later seventeenth century tended in their royalist concerns to overlook the Cromwellian interregnum, while the heroic symbol of the Protestant ascendancy rested not in Cromwell but William III, 'a man not without [his own] embarrassing blemishes, but altogether less dangerous than Cromwell'. If anyone was to be the great enemy, it was the Protestant James Butler, the duke of Ormonde, or on a lesser level Murrough O'Brien, Lord Inchiquin, who recovered their estates during the restoration of Charles II and, in the former's case, oversaw new or existing land transfers into the hands of a Protestant minority. ${ }^{3}$ Meanwhile, the eighteenth century, while rich in Irish historical and literary activity, witnessed Catholic and Protestant histories that focused not on 1649 or the 1650 , but on the rising of 1641, the Restoration, and the Williamite settlements, with Cromwellaccording to Barnard-presented as an honourable enemy rather than a 'duplicitous fiend'. It was not until the works of J.P. Pendergast and W.E.H. Lecky, both Victorians, that a darker Cromwell came forth, with Lecky writing that Drogheda and Wexford and the subsequent resettlements 'made the name of Cromwell eternally hated in Ireland', leading to the deep and sustaining antipathy 'both of England and of Protestantism'. ${ }^{4}$

Lecky's remark that Cromwell had been 'eternally hated' reveals, however, that the calamitous legacy of the conqueror was very much remembered, and demonised, long before nineteenth-century partisan historians or folklorists discovered his use as an effective villain. For the previous two centuries Cromwell had already appeared in a variety of forms across oral

3 See Coleman A. Dennehy, Restoration Ireland. Always settling and never settled (Aldershot and Burlington: VT: Ashgate, 2008), 167ff. For Ormonde's reputation, see Éamon Ó Ciardha, 'The unkind deserter' and 'the bright duke'. Contrasting views of the dukes of Ormonde in the Irish royalist tradition', in Toby C. Barnard and Jane Fenlon (eds.), The dukes of Ormonde. 1610-1745 (Woodbridge: Boydell Press, 2000), 177-194.

4 For memory and 1641, see Ireland: 1641: Contexts and Reactions, ed. Micheal O Siochru and Jane Ohlmeyer (Manchester: Manchester University Press, 2013); John Gibney, The Shadow of a Year: The 1641 Rebellion in Irish History and Memory (Madison, WI: University of Wisconsin Press, 2013). Toby C. Barnard, 'Irish images of Cromwell', in Roger C. Richardson (ed.) Images of Cromwell (Manchester: Manchester University Press, 1993), 180-206; Jason McElligott, 'Cromwell, Drogheda, and the abuse of Irish history', Bullán. An Irish Studies Review 6:1 (2001), 109-132. McElligott takes issue with Barnard's sole focus on the histories of literate Irish elites as well as his failure to explore the oral or folkloric tradition; rather than trace this other tradition back in time, however, McElligott himself cites only a few nineteenth-century folklorists, thus implying that the Cromwell of enduring and hated memory, in other words, did not truly become a presence as such until elite historians, writers of textbooks, and professional folklore anthologists deemed him so. See also William E.H. Lecky, A history of Ireland in the eighteenth century (London: Longmans, Green \& Co, 1906), vol. 1, 101. 
and popular culture, in response to an experience of deep rupture that he had effected in Irish history. Yet these earlier memories-contained in poetry, folklore, or popular religion-resist modern expectations of what collective memory (or for that matter, history) is to be since they play loose with historical details or avoid psychological accounts of the 'traumatic', particularly if that term is taken in its modern sense as a sudden, violent, accidental and contingent intrusion of the 'meaningless' onto existing frames of thought. ${ }^{5}$ In the years immediately following the conquest, for example, martyrologies, sermons, and eyewitness letters told of priests being summarily executed by Cromwell's men, which was true enough, though such accounts also described the killing of 'virgins', thus connecting the massacres to the virgin martyr legends from centuries before; ${ }^{6}$ religious folklore of the seventeenth century onward echoed these stories, which also described resistance in the form of monks hiding treasures from Cromwell's invading men or fleeing their monasteries with their books - which also surely occurred, even though the reference also directly echoed older stories related to medieval Irish monastic traditions. More than simply chronicles or victimologies of the deaths occurring under Cromwell, these stories were thus memorialisations of catastrophe assigned to transcendental or providential categories, which occurred in a distinctly pre-modern, enchanted world.

Though their work is imbued in already existing literary conventions, poets such as Brian Mac Giolla Phádraig (d. 1652) or Aogán Ó Rathaille (d. 1729) for their part lamented the world lost under Cromwell and the conquerors before and after him, with Mac Giolla Phádraig-as a priest, executed by Cromwell's men in 1652 - writing, 'A trick of this false world has laid me low: servants in every home with grimy English but no regard for one of the poet class save "Out! and take your precious Gaelic with you!" '7 But an altogether different Cromwell also appeared as a character in folkloric mummers plays, beginning in the late seventeenth and early

5 See Cathy Caruth, Unclaimed experience. Trauma, narrative and history (Baltimore and London: Johns Hopkins University Press, 1996); see also Shoshana Felman and Dori Laub, Testimony. Crises of witnessing in literature, psychoanalysis and history (London and New York: Routledge, 1992).

6 Patrick Corish and Benignus Millet (eds.), The Irish martyrs (Dublin: Four Courts Press, 2004), esp. 181-201; Clodagh Tait, 'Adored for saints. Catholic martyrdom in Ireland c. 1560-1655', Journal of Early Modern History 5 (2001), 128-159.

7 See Tom J. Dunne, 'The Gaelic response to conquest and colonisation. The evidence of the poetry', Studia Hibernia 20 (1980), 7-30; Nicholas Canny, 'The formation of the Irish mind. Religion, politics, and Gaelic Irish literature, 1580-1750', Past and Present 95 (1982), 91-116. 
eighteenth centuries, with his large copper nose and his boastful nonsense ('Here comes I, Sir Oliver Cromwell, With my large and copper nose. I made the Frenchman for to tremble, and the Germans for to quake, I bet the jolly Dutchman coming home from the wake'). ${ }^{8}$ Both the mumming genre and the nose - a universally significant motif in folklore-had migrated over from England, after gaining popular currency in depictions by royalist polemicists and satirists; for all the violence of the civil wars in England, however, Cromwell carried a different history in Ireland, which made the Irish mumming of Cromwell noteworthy in being denuded of all biographical detail, and rendered peripheral and utterly powerless in the legendary pantheon of other mumming characters such as Beelzebub (Cromwell's partner) or St Patrick. ${ }^{9}$ But a darker kind of diabolism was also at work in yet other migratory tales, which told of Cromwell training his men under the flag of the devil, or sealing various pacts with Satan, or serving as a bogeyman, or as the instigator of a curse or insult ('the curse of Cromwell on you'). ${ }^{10}$ The memorialisations of Cromwell were therefore not simply diverse, but multimedial and multidirectional, extending across oral and print expressions, high and low culture, regions and countries, the archaic world before and its modern aftermath.

Nowhere was Cromwell memorialised more insistently, however, than in the very land that he affected through his policies of confiscation, expulsion, and re-settlement. ${ }^{11}$ Landscape had always functioned as

8 For a recent and incisive treatment of the mummers and folk drama around the world, see Steve Tillis, Rethinking folk drama (Westport, CT and London: Greenwood, 1999); see also Alex Helm, The English mummers' play (London: Brewer for the Folklore Society, 1981); for traditional and more recent approaches to the performance in Ireland and England, see for example Alan Gailey, Irish folk drama (Cork: Mercier Press, 1969); Reginald J.E. Tiddy, The mummers' play (Oxford: Clarendon Press, 1923); Alan Brody, The English mummers and their plays. Traces of ancient mystery (Philadelphia: University of Pennsylvania Press, 1970); Susan Pattison, 'The Antrobus soulcaking play. An alternative approach to the mummers' play', Folk-Life 15 (1977), 5-11; Bryan Jones, 'Christmas mumming in Ireland', Folklore 27 (1916), 301-307; H. Coote Lake, 'Mummers' plays and the 'sacer ludus', Folklore 42 (1931), 141-149; Alan Gailey, 'Chapbook influence on Irish mummers' plays', Folklore 85 (1974), 1-22. See also William Smith Clark, The early Irish stage. The beginnings to 1720 (Oxford: Clarendon Press, 1955), 3-8 and William Smith, The Irish stage in the county towns, 1720 to 1800 (Oxford: Clarendon Press, 1965).

9 Laura Lunger Knoppers, Constructing Cromwell. Ceremony, portrait, and print 1645- $^{-}$ 1661 (Cambridge: Cambrigde University Press, 2000), esp. 11-15, 46-50.

10 For Cromwell and the Irish cursing tradition, see for example William Carleton, Traits and stories of the Irish peasantry, ed. D.J. O'Donoghue (London: J.M. Dent and New York: Macmillan, 1886), 213; for a longer history of the curse, see also Bernard Mees, Celtic curses (Woodbridge: Boydell Press, 2009).

11 See Karl Bottigheimer, English money and Irish land. The adventurers in the Cromwellian settlement of Ireland (Oxford: Clarendon Press, 1971); for Cromwellian governance, 
a mnemonic device in Ireland, beginning with the ancient tradition of dinnseanchas, a kind of story-lore in which features of the landscapetrees, rocks, wells - were imbued with tales of origin, implying, in Seamus Heaney's words, 'a system of reality beyond the visible realities' ${ }^{12}$ This symbiosis between lore and landscape — or, to put it another way, the narrativisation and at times sacralisation of landscape-imbued that landscape with emotion, resulting in what Yi-Fu Tuan has called 'topophilia', or the affective bond between people and their place or setting. ${ }^{13}$ Story telling made this bond possible, since 'narratives [served to] vivify the landscape, transforming it from a neutral piece of territory into a stage set for ever evolving and changing historical events'. Yet as Kent Ryden has written, if 'place enfolds relationships, relationships shape memories, memory sparks stories, [and] stories cling to place with such tenacity', then 'the destruction of place threaten[ed] the entire structure'. ${ }^{14} \mathrm{Crom}$ well's severing of the connection between people and their environment thus threatened to dislocate all the associations and memories contained within that connection; yet as this essay will argue, while Cromwell disrupted that bond, he did not destroy it. Instead, with his presence came a new archaeological layer of narrative that was inscribed onto the landscape, as rocks, wells, and ruins become new 'places of memory', even if those places were now testimonials to the violence and dispossession that he and his soldiers inflicted.

Thousands of stories attest to remembrance of Cromwell in the National Folklore Collection at University College Dublin, an archive of memory that grew out of the National Folklore Commission established in 1935, after decades of folkloric collecting and anthologizing in Ireland. ${ }^{15}$ Containing

see Toby C. Barnard, Cromwellian Ireland. English government and reform in Ireland, 16491660 (Oxford: Oxford University Press, 1975).

12 Seamus Heaney, Preoccupations. Selected prose 1968-1978 (London: Faber \& Faber, 1980), 132. For the role of landscape in memory, see Katharina Schramm, 'Landscapes of violence. Memory and sacred space', History and Memory 23 (2011), 5-22; Christopher Tilley, 'Introduction. Memory, place, landscape and heritage', Journal of Material Culture 11 (2006), 7-32, there 8; Barbara Bender (ed.), Landscapes, politics and perspectives (Providence and Oxford: Berg, 1993); and Barbara Bender and Margot Winer (eds.), Contested landscapes. Movement, exile and place (New Yorkand Oxford: Berg, 2001).

13 Yi-Fu Tuan, Topophilia. A study of environmental perception, attitudes, and values (Englewood Cliff, N.J., and London: Prentice-Hall, 1974).

14 Kent C. Ryden, Mapping the invisible landscape. Folklore, writing, and the sense of place (Iowa City: University of Iowa Press, 1993), 94.

15 For a description and analysis of the National Folklore Archive and its implications for historical study and memory, see Guy Beiner, Remembering the year of the French. Irish folk history and social memory (Madison, WI, and London: University of Wisconsin Press, 2007), esp. 36-37. 
manuscripts of oral and ethnological material transcribed from interviews and questionnaires in the 1920 s and 1930s, the collection contains many hundreds of references to Cromwell, who ranks second to Daniel O'Connell in the amount of material devoted to him. With the exception of scholars such as Guy Beiner, however, early modern historians have avoided these archives, viewing them not as traces from a deep past but as products that reflect late nineteenth- and early twentieth-century land policy concerns or incipient nationalist sentiments on the eve of a country's independence. For Barnard, many of these folkloric deposits are difficult to locate in time and therefore should be dismissed from historical analysis, constituting as they do a possibly invented tradition rather than evidence of cultural persistence. ${ }^{16}$ Yet too many recurring motifs and tropes connect the transcribed tales to the relatively scanty early modern folkloric evidence for scholars to entirely dismiss those latter-day sources as corrupted products of bias-driven nationalists. Taking into account their inherent distortions, tales written down in the twentieth century can be measured against the more fragmentary evidence of the past, in sources such as sermons, pamphlets, almanacs, early travel accounts, and even tombstones, to recover some evidence of oral attitudes across time. ${ }^{17}$ As Peter Burke has pointed out, if treated cautiously, such stories thus have the potential to reveal the attitudes and mentalities of a past society and as such are able to extend the historical agenda into new and significant directions. ${ }^{18}$ In addition, and particularly in the case of Ireland, folklore, or one could say 'popular' memory, carried the potential to subvert the past and manipulate trauma towards a different, imaginative Irish history, even if the channel to do so was by way of an intentional or unintentional misremembrance of that past, across the early modern and modern periods. ${ }^{19}$

The many iterations of Cromwell in early modern and modern Irish memory lead one to question why he alone merits all the attention in the first place. Cromwell was certainly not the only one to oversee acts

16 Barnard, Cromwellian Ireland, 187.

17 See for example the 1667 tomb in Kilconnell, Galway, of Matthias Barnwell, the 12th Baron of Trimblestown: '... transplanted to Connaught [by] the usurper Cromwell'. (H.V. Morton, In search of Ireland (London: Methuen, 1931)), 62. I wish to thank Kevin Whelan for this reference.

18 Peter Burke, Popular culture in early modern Europe (New York: Harper and Row, 1978), esp. $65^{-87}$.

19 For the usefulness of studying folklore in Irish history, see Beiner, Irish folk history, esp. 17-33. See also Linda Dégh, 'Oral folklore. Folk narrative', in Richard Dorson (ed.) Folklore and folklife. An introduction (Chicago: University of Chicago Press, 1972), 53-83. 
of sometimes shocking violence and radical land reconfigurations, which had begun with the increasingly brutal attempts by the Tudors to suppress rebellion and re-exert control over the land. ${ }^{20}$ The first and second Earl of Essex, Henry Sidney, Lord Grey de Wilton, Lord Mountjoy, Arthur Chichester all preceded Cromwell as agents of this more ruthless colonisation; even in his own time, it would not be defending Cromwell to point out that contemporaries such as Charles Coote or Roger Boyle, Lord Broghill, overtook him in methods of brutality when it came to relations with the Irish. ${ }^{21}$ Cromwell, however, represented the culmination of over one hundred years of Tudor-Stuart conquest, signalling the final defeat of the old Gaelic aristocracy and English-Irish order (his being 'the war that finished Ireland');22 though he represented the last in a continuum of conquest and appealed to previous biblical and providential models, he was also radically modern, not only in the army he brought with him but in the administrative centralisation, planting schemes, utilitarianism, and Protestant ascendancy that came in his wake. Indeed, he had even killed a king. No other English antagonist was therefore so given over to an already-existing and extensive mythmaking process undertaken by admirers, enemies, and, not least, by Cromwell himself; as a result, his persona was adaptable to different frames of narrative and meaning, giving rise to an array of alternative memories that ran parallel or counter to the more conventional histories. Attention to such material is thus important, for as Michel-Rolphe Trouillot has written, we need to be reminded that 'the production of historical narratives involves the uneven contribution of competing groups and individuals who have unequal access to the means of such production'; despite the importance of the official and linear histories, the popular and often contested 'recollections' of more marginal groups are 'no less powerful' in their own contributions to the memorialisations that define a country. ${ }^{23}$

20 See Clodagh Tait, David Edward and Pádraig Leninhan, 'Early modern Ireland. A history of violence', in Edwards, Lenihan and Tait (eds.), The age of atrocity, 9-32.

21 James Scott Wheeler, Cromwell in Ireland (New York: Macmillan, 1999), 5. See also John Morrill, 'The Drogheda massacre in Cromwellian context', in Edwards, Lenihan and Tait (eds.), Age of atrocity, 242-265; Patrick Little, Lord Broghill and the Cromwellian union with Ireland and Scotland (Woodbridge and Rochester, NY: Boydell Press, 2004), 59-90.

22 See the anonymous poem containing the phrase 'an Siogai Romanach' ('the war that finished Ireland'), in James Hardiman (ed.), Irish minstrelsy, or bardic remains of Ireland (London: Robins, 1831), vol. 2, 306-388.

23 Michel-Rolph Trouillot, Silencing the past. Power and the production of history (Boston: Beacon Press, 1995), xix; Jeffrey K. Olick and Joyce Robbins, 'Social memory studies. 
Memory itself does not recall past events so much as it makes meaning out of them, thereby forging a common identity and affective bonds among closed communities of shared values. ${ }^{24}$ It is therefore not synonymous with history, though the manner in which the landscape was memorialised and narrativised in post-Cromwellian Ireland cannot be fully discussed without a larger understanding of what he actually did to that landscape. Under Cromwell more than any previous ruler or administrator, Ireland's geography, in William Smyth's words, became 'the visible symbol of colonial rule', not only in terms of the confiscation and division of land for adventurers and soldiers, but in the more efficient mapping and surveillance of that land (in the cartographic work of William Petty and the censuses respectively). ${ }^{25}$ Over 10,000 landowners were forced to renounce their estates in accordance with the Commonwealth legislation; ${ }^{26}$ perhaps 45,000 people travelled west, to the more barren regions of Connaught, though the vast majority stayed where they had lived, residing now as tenants and thereby subject to vast social upheavals that also carried implications in terms of their new relationship to the land. The overall depopulation of Ireland's landscape also carried implications for the perpetuation of collective memory, with a fortytwo per cent decline in population from 1641 to $165^{2}$-due, it should be said, to the 1641 uprising and confederate campaigns as well as Cromwell's actions. Meanwhile, these developments took place in a landscape laid waste by a scorched earth policy conducted in the years $165^{\circ}$ to 1653 , after Cromwell had left; this left 11 million acres, half of Ireland, requiring planting, which would be conducted by New English owners and settlers. Planning was thus set in motion, as Smyth puts it, for 'the phenomenal transformation of the economic, cultural, and political geography of Ireland', as the 'whole island now lay at the mercy of the Commonwealth'. ${ }^{27}$

In this new dispensation, maps became instruments of state power in the administration and control of territory, in order to regulate, allocate, and tax the newly confiscated lands. This was not new to the Cromwellian period; for Attorney General Sir John Davies, writing in the early seventeenth

From "collective memory" to the historical sociology of mnemonic practices', Annual Review of Sociology 24 (1998), 105-124.

24 See Kerwin Lee Klein From history to theory (Berkeley, CA: University of California Press, 2011), 116.

25 Bottigheimer, English money and Irish land.

26 Jane Ohlmeyer, Making Ireland English. The Irish aristocracy in the seventeenth century (New Haven and London: Yale University Press, 2012), 28off.

27 Smyth, Map-making, 170. 
century, mapping was not only an instrument of state control, a means by which 'every plot of land' could be made 'amenable to state regulation, allocation, inspection and taxation', but it also represented a form of knowledge, a science that reflected English colonial identity. By contrast, the rejection of this cartographic science was made unfortunately manifest in the murder of the military cartographer Richard Bartlett by the inhospitable natives of Ulster, who-in John Davies' words, 'would not have their country discovered'. ${ }^{28}$ Despite this setback, the colonizing mapping of Ireland continued, resulting in William Petty's famous and unprecedented Down Survey of the 1650s; like Bartlett, Petty worked within a military context, which would continue into the nineteenth century as Ordnance Survey mappers worked alongside sappers to 'name, own, and reconfigure' the landscape. In all cases, the progression was the same, writes John Andrews, as colonial cartography moved seamlessly from 'regional sketches to fort plans, and thence to plantation surveys and estate plans'. 29

Maps for the English thus served as a form of printed and therefore fixed (though not necessarily public) knowledge that stood in contrast to a landscape memory that was primarily oral, mostly localised, inaccessible to outsiders, and passed down through generations-in other words, the landscape knowledge held by the Irish or Old English. Most scholars focus on the permanent record and representation of landscape conducted by the English on the Irish; it is important, however, to understand this counter-knowledge of the land that persisted in the midst of these new cartographic and surveying impositions, particularly as they existed as a response and even a form of resistance to the official record of a Down Survey. The oral record as it exists in the National Folklore Collection and earlier transcriptions, for example, repeatedly echoes not with memory of the massacres at Drogheda and Wexford but with the land and its transference away. 'The time that Cromwell came to Ireland [and] put the people out of their lands and gave it to his own soldiers' is a repeated statement, occurring in reminiscences from all counties, in originary tales of how one property was gained, lost, or subject to different machinations or trickery on both sides. Some tales simply recall the bare facts, as with

28 C.W. Russell and John P. Pendergast (eds.), Calendar of state papers, Ireland, James I, 1608-1610 (London: Longman, 1874), 280.

29 See John Andrews, Shapes of Ireland. Maps and their makers 1564-1839 (Dublin: Geography Publications, 1997), p. 118. See also John Andrews, A Paper landscape. The ordinance survey in nineteenth-century Ireland (Oxford: The Clarendon Press), 1975. 
one eighteenth-century description of a Wexford bishop, born in Kilkenny, whose grandfather had lost 'a very large [estate] by Cromwell's sanguinary proscriptions'. ${ }^{30}$ Or: 'There was a man and his name was [Carson]. He had [six?] miles of the best land and there was nothing living on it but horses, cattle and sheep and he even had the rabbits. No one could take one rabbit out of the [fields]'.31 The term 'sanguinary' reappears again, in the more heated early nineteenth-century memoir of Miles Byrne, who spreads the blame more widely, writing that the land belonging to his ancestors remained with 'the descendants of the sanguinary followers of Cromwell, who preserved their plunder and robberies after the restoration of that scoundrel Charles II' ${ }^{32}$

Yet numerous examples also exist that reveal agency on the part of Irish who outwit the colonialist presence through cleverness or opportunity. ${ }^{33}$ Thus does a stonebreaker provide dinner for a half-starved Cromwellian soldier who is on his way to claim land (or 'ill-gotten gains'); as payment for dinner, the stonebreaker is given a grant of 2000 acres in return. Another tale recounts Cromwell expelling monks from an abbey and bequeathing the property to a tinker 'breaking stones on the side of the road'; afterwards he was given his demanded reward - the property - in return for directions to the place. ${ }^{34}$ The reality, of course, was different, with no rewards for tinkers and stone-breakers. As William Smyth has pointed out, the allocation of land during the Cromwellian settlement was not only relatively systematic but undertaken with military discipline; while exceptions did occur, fierce competition frequently existed between the claims of the army and those of the adventurers back home, who had been promised land in return for their financial support of the campaign ${ }^{35}$ _all very different from the claims of the alternative folkloric narrative.

Mapping and surveying also required the redesignation or anglicizing of place-names - a process most famously memorialised in Brian Friel's play

30 Finn's Leinster Journal, 1 November 1786 (Carrigan, Ossory, iii, 333). For other droll examples, see also The Parliamentary Gazeteer of Ireland (Glasgow, 1844), 744; National Folklore Collection, University College Dublin, Main Manuscript Collection (hereafter IFC), \#1417, I.4.

31 IFC \#1405, I.134.

32 Miles Byrne, Memoirs I (Dublin: Maunsel, 1907), 3.

33 See for example Thomas Crofton Croker (ed.), The tour of the French traveller M. de la Boullaye le Gouz in Ireland (London: T. and W. Boone, New Bond Street, 1837), 28 (n. 54), 98 .

34 National Folklore Collection, University College Dublin, Schools' Manuscript Collection (hereafter IFC S), \#862,I.313.

35 Smyth, Map-making, 190-191. 
Translations regarding the nineteenth century, even if the Englishing of the landscape began much earlier. ${ }^{36}$ In this regard, and as in a palimpsest, English names were superimposed onto the landscape, overlaying if not altogether erasing the traces of previous names and the memories behind them. But once again, the oral and literary culture perpetuated its own counter-naming processes that incorporated and subverted Cromwell's presence; the town of Dundrum, for example, was said to have earned its name when one of the drummers in Cromwell's army decided to quit his position and settle where he was, claiming, 'I'm done drumming'. In actuality, Dundrum - a suburb of Dublin — was not founded by a Cromwellian but was an ancient location centred on a church and dating to the sixth century and fortified by the Normans beginning in the twelfth century. In addition, many of the names did not simply mark destruction and loss but also memorialised the death of Cromwell's own men, and by the same token, the small victories of Ireland's defenders. Tales were woven of the Trooper's Mound in Westmeath, where many Cromwellian soldiers were said to have been killed and buried; or in Sligo, a sheer drop into a ravine known as the 'Protestant Fall', where Cromwellian soldiers plunged after being tricked to go there by locals. ${ }^{37}$ Such informal, unofficial names were significant for they helped to consolidate identity in the encoding of language and historical referents in a manner closed to outsiders, all of which was important as a means to grasp agency in a world of otherwise overwhelming impositions. ${ }^{38}$

Cromwell in the folklore was himself said to have joined in with the unofficial place-naming, as illustrated by one folk story, which also captures the yoking of Cromwell to a range of motifs and therefore deserves some analysis in its own right. 'Cromwell was a big English general and a bad man', begins the tale from the West; 'He'd stick the bayonet in the child and hold it up in the air until one of his officers would fire a shot through it. When he came to County Clare, he never halted until he came as far as Spancil Hill and 'twas Cromwell that started the first horse fair in Spancil Hill on June twenty-third'. ${ }^{39}$ Keeping in mind that folk tales truly come alive only in the telling and that they are characterised by

36 Smyth, Map-making; Ted McCormick, William Petty and the ambitions of political arithmetic (Oxford: Oxford University Press, 2009), 117.

37 IFC S. \#156, I.150-52.

38 Gerry Smyth, Space and the Irish cultural imagination (New York and Basingstoke: Palgrave Macmillan, 2001), 48-51.

39 See Henry Glassie, Irish folk tales (New York: Pantheon Books, 1985). 
ever-changing fluidity in narrative, the odd juxtapositions within this story are nevertheless revealing. On the one hand, the recounting of the murdered child reflects a time-worn trope of atrocity literature extending back through ancient times and most recently appearing in English pamphlets as well as John Temple's martyrological account written in the wake of the 1641 uprising - an account that told dozens of lurid tales relating to babies being piked, hanged on clothes lines, or of course taken from their mothers' wombs. But to follow the image of the baby with a straightforward account of the first horse fair in Clare brings a banality to the story, resulting in the fusion of fiction with fact, the nowhere of place (it is not clear where Cromwell 'ordered the execution' of the child) with the topographically specific (Spancil Hill, Clare). The tale thus captures both dimensions of the colonial experience - the malignant and the ordinary, the moral and the utilitarian, the bad and, with the horse fair, the arguably good; it reflects the capaciousness of memories to hold contradictions within themselves, while also expressing ambiguity of experience.

Much of the folklore derived from the territories around the Pale, which may account for the transmission of a vibrant Cromwellian-related oral culture to and from England, based on common motifs. ${ }^{40}$ Cromwell's copper nose has already been mentioned, as it circulated in England and then migrated over, as a kind of floating legend, to Ireland. The persistent theme of Cromwell's ubiquity was also evident in English popular culture, where he appeared in bodily form in places he had never visited or as a spectre drifting across the land; as in Ireland, English folklore also abounded with stories of Cromwell stabling his horses in churches, leaving behind the impression of hoofprints on the floor. But differences in the folklore are also revealing. Protestant England did not have additional tales of monks being thrown into rivers, priests being hanged from trees, crosses being smashed, holy water fonts miraculously surviving destruction, chalices and the gold of monasteries and churches being

40 Alan Smith, 'The image of Cromwell in folklore and tradition', Folklore 79 (1968), 17-39; Seán Ó Súilleabháin, 'Oliver Cromwell in Irish oral tradition', Folklore Today (1976), 73-483; Adam Fox, 'Remembering the past in early modern England. Oral and written tradition', Transactions of the Royal Historical Society 9 (1999), 233-256, there 241. For oral culture in England in general, see for example Daniel R. Woolf, "The "common voice". History, folklore and oral tradition in early modern England', Past and Present 120 (1988), 26-52; Walter Johnson, Folk memory, or the continuity of British archaeology (Oxford: Clarendon Press, 1908), 13; Michael T. Clanchy, 'Remembering the Past and the Good Old Law', History 55 (1970), 165-176, there 167 ; Keith Thomas, The perception of the past in early modern England. The Creighton Trust Lecture 1983 (London: University of London, 1984), 8-9. 
buried or preserved as relics, and appearances arising of the Blessed Virgin. In Ireland, landscape thus became more connected than ever before to Catholic imagery and iconography - a connection which of course had existed for centuries, though not to the extent that the land was called upon to resist an unprecedented invader, and one who framed his own conquest in godly terms.

In martyrological and popular literature as well as folklore, fugitive priests on the run from Cromwell and his men also constituted a frequent motif as they assumed a kind of itinerancy that mirrored Cromwell and his soldiers' own roaming omnipresence. ${ }^{41}$ More noteworthy than tales speaking of sympathisers coming to the aid of such men are stories of the land itself, alive with faith, and rising up in resistance. Rocks especially served as active protectors of the besieged innocent; in one story, a hunted priest is chased on the Mullet peninsula by Cromwell's men until he finds refuge on the beach, under rocks which miraculously appear and hide him successfully until his own people arrive. ${ }^{42}$ The priest is significant not only in asserting a Catholic dimension to a man-and by extension, a country - under siege, but it also once again reinforces Catholicism as an essential component in an oppositionally defined identity and presents the landscape itself as a divine intercessor in the resistance against evil.

Ruins also became part of the memory landscape, with Cromwell's targeting of monasteries and churches a constant reminder of defeat (even if many of those monasteries first entered their decline if not destruction under Henry VIII). In his travels with Mountjoy, the aforementioned cartographer Richard Bartlett, for example, sketched a number of 'new' ruins, most notably O'Neill's burned and destroyed castle at Dungannon, now with the flag of St George flying over it. ${ }^{43}$ In the eighteenth century, the sketches of English or Anglo-Irish antiquarians such as James Boyle tended to collapse Cromwellian ruins with megalithic monuments, castles, and churches, thus projecting Cromwell's legacy into a misty past. Others were

41 See Nicholas French's seventeenth-century Apologia, written upon his departure from Ireland, quoted in Denis Murphy, Cromwell in Ireland. A history of Cromwell's Irish campaign (London: M. H. Gill \& Son, 1885), 163-164.

42 See for example John Lynch, Cambrensis Eversus, seu potius Historica fides in rebus Hibernicis Giraldo Cambrensi abrogata; in quo plerasque justi historici dotes desiderari, plerosque nævos inesse, ostendit Gratianus Lucius, Hibernus [pseud.], qui etiam aliquot res memorabiles Hibernicas veteris et novæe memorice passim e re nata huic operis inseruit: impress. an. MDCLXII (Dublin: Celtic Society, 1848), vol. 1, 82, 166 (n. 42.)

43 Glenn Hooper, 'Planning control. Cartouches, maps and the Irish landscape', in Glenn Hooper (ed.), Landscape and empire, 1770-200o (Aldershot and Burlington, VT: Ashgate, 2005), 40. 
not so romantic about the legacy, however. In the early eighteenth century, Jonathan Swift, for example, would refer to Cromwell's ruins in the following words, 'Examine all the eastern towns of Ireland, and you will trace this horrid instrument of destruction, in [defaced] churches...nine in ten of them lying among their graves and God only knows when they are to have a resurrection'. Like Cicero on his return from Asia, Swift surveyed all before him, as it lay 'prostrate and in ruin' - due, he wrote, to Cromwell. ${ }^{44}$

The ruins of a landscape could also bear the folkloric mark of Cromwell, as in the Round Tower on Aran (which actually was felled in a gale), numerous stone crosses (evidence of Romanism), or various castles ('If any great man stood against him, he would pull down his castle'). ${ }^{45}$ As one Ordnance Survey administrator was to write in the early nineteenth century, 'almost every devastation of the kind is attributed to [Cromwell], perhaps with some justice, as he certainly could not be charged with any great love of popery or its emblems' ${ }^{46}$ English ruins thus represented the distressing aftermath of Cromwell's regime, but they also embodied another meaning distinctive to the land. In Kevin Whelan's words, if the Enlightenment and Romantic English ideal held that ruins were a nostalgic reminder of a vanquished past, yet one that held continuity to the present, as a mature living state 'recalled' its childhood, the ruins of Ireland, 'from an anti-colonial Irish perspective', were seen as a 'traumatic tear in the fabric of time', with tradition and custom 'not based on continuity but on violence, instability, and discontinuity'. In this sense, ruins were 'materialisations of the colonised's defeat, the presence of absence, in which the long-term effects of historical trauma [became] fixed in place' ${ }^{47}$

44 Jonathan Swift, Works (London, 1900), vol. 13, 29.

45 See, however, Smyth, Map-making, 164 for the number of ruined castles in Co, Tipperary in 1654 .

46 Ordnance Survey Letters (hereafter OS), MS 389 (bk 118, 1839); Parish Church of Clonmore [Carlow].

47 Kevin Whelan, 'Reading the ruins. The presence of absence in the Irish landscape', in Howard B. Clarke et al. (eds.), Surveying Ireland's past. Multidisciplinary essays in honour of Anngret Simms (Dublin: Geography Publications, 2004). See also Luke Gibbons, 'Romanticism in ruins. Developments in recent Irish cinema', The Irish Review 2 (1987) 59-63; Luke Gibbons, 'Between Captain Rock and a hard place. Art and agrarian insurgence', in Tadhg Foley and Seán Ryder (eds.) Ideology and Ireland in the nineteenth century (Dublin: Four Courts Press, 1998); and Georg Simmel, 'The ruin', in Kurt H. Wolff (ed.) Georg Simmel, 1858-1918. A collection of essays with translations and a bibliography (Columbus, OH: Ohio State Univ Press, 1959), 266. Georg Simmel wrote of ruins that the past with its destinies and transformations has been gathered into this instant of an aesthetically perceptible present'. 
It was perhaps inevitable that the great issues of the nineteenth century - namely, land tenure and reform, Catholic emancipation, and rising nationalism - would also lead to the invocation of Cromwell's name, which by then had assumed the form of a kind of imaginative and all-purpose signifier, a symbol of what one nineteenth-century newspaper called the 'land hunger of the Anglo-Saxon race'. ${ }^{48}$ And Cromwell was certainly a fitting name to recall, since the various Land Acts of the later nineteenth and early twentieth centuries were attempts to address discriminatory ownership laws that derived from Cromwellian policy and reached their peak in the eighteenth century. Accompanying these attempts to reform property ownership and land tenure by also looking again to where it all originated were parallel developments in historiography and poetry that placed a new kind of emphasis on the violence of the Protector, and his role as the 'butcher of Drogheda and Wexford'. Celtic revivalists such as Yeats, however, would not cast hatred onto Cromwell as much as they would attempt to scratch him from the record or limit his presence severely in their own folklore anthologies; for them, Cromwell represented an interlude best left forgotten in the quest to retrieve a more authentic and mythical-indeed, a yet earlier pre-modern and archaicIrish past. As Declan Kiberd has written, for Yeats the 'Cromwellian' encompassed not only imperialism but dreary, dream-barren middle class consciousness as well as the leveling vulgarity of the Cromwellian planters'. ${ }^{49}$ Yet for all the ruins he left behind, and despite the effacements of Yeats, Cromwell also stood at a positive place in the formation of an emerging Irish identity, beginning not in the nineteenth century but in the early modern period; the fact that he 'lived on' in different guises as well as regions and counties - most of which, again, never bore his actual presence-served to unite the country through a common if regionally varied constructed 'memory' that conveyed agency and resistance in the period of the Protestant ascendancy.

Whether sinister or comic, physically embedded in the land or traveling from county to county, the Cromwell of early modern memory thus represented the source of different living fictions that rebounded through the diverse and regional popular cultures. ${ }^{50}$ Landscape lore particularly

\footnotetext{
48 Quoted in John P. Pendergast, The Cromwellian settlement of Ireland (London: Longmans, Green, Reader and Dyer 1870), 135 (n. 2).

49 Declan Kiberd, Inventing Ireland. The literature of a modern nation (New York: Random House, 2009), 483 .

50 Trouillot, Silencing the past, xix.
} 
grounded Cromwell spatially and temporally in a place, as a 'thing that happened here', or as a force which was both 'factual and mythic', claiming the rocks or the sea at the same time that those topographical features could rise up against him. Yet to incorporate Cromwell into popular memory was also, in a sense, to bring him into the national story, and landscape, of Ireland and to perhaps even make a claim on him as well. He was alien because the soil rejected him or brought magpies which darkened the skies, strange birds bearing ill-fortune; but the Cromwell of popular memory was also fused onto existing folkloric tropes, or incorporated into a long-held Irish pantheon of myth. He was a devil, a usurper, a conqueror, yet his engagements with the land and its people - and on a larger level its myths and folklore-transformed him into something distinctly 'Irish' as well. Perhaps this is one reason for the bizarre tales that speak of Cromwell being born and raised in Ireland, or even ascending to the Irish kingship, before leaving for England and returning as a conqueror, to betray his own people. Such was the distinctly 'pre-modern' memory that persisted alongside later narratives: a more dynamic, diverse, and contested set of memorialisations than the linear and historical accounts of modernity but no less important for the way they affected a changing national identity, and one based, then as before, in the land and the stories it told. 